\title{
Relationship between concentration of crude protein in spring barley (Hordeum vulgare L.), white goosefoot (Chenopodium album L.), charlock (Sinapis arvensis $\mathrm{L}$.$) and prickly grass (Echinochloa crus-$ galli (L.) Beauv.)
}

\section{Vytautas Pilipavičius}

Aleksandras Stulginskis University, Studentu St. 11, LT-53361 Akademija, Kaunas Distr., Lithuania
Laboratory bioassay was carried out at the Laboratory of Agronomic and Zootechnical Research of the Lithuanian University of Agriculture (Aleksandras Stulginskis University) at 54 ${ }^{\circ} 89^{\prime} \mathrm{N}$ and $23^{\circ} 83^{\prime} \mathrm{E}$ during 2004-2005. The field experiment from which plant samples were taken for the laboratorial bioassay was performed in 2003-2004 in spring barley Aura crop at the Experimental Station of the Lithuanian University of Agriculture at $54^{\circ} 52^{\prime} \mathrm{N}$ and $23^{\circ} 49^{\prime} \mathrm{E}$.

The Lithuanian territory occupies an intermediate geographical position between the west European oceanic climate and the Eurasian continental climate. Lithuania belongs to the western region of the Atlantic Ocean continental climatic area with the average annual precipitation of $675 \mathrm{~mm}(572-978 \mathrm{~mm})$ and temperature of $6-7^{\circ} \mathrm{C}$.

The change of crude protein concentration in weeds affects accumulation of crude protein in spring barley. The aim of the experiment was to establish the dependence of spring barley biomass crude protein concentration on crude protein concentration in white goosefoot, charlock and prickly grass biomass from the same agrophytocenosis. The plant biomass taken from organic and conventional agriculture crops was evaluated for crude protein concentration by the Kjeldahl method.

The highest concentration of crude protein in the biomass was established in the conventional agriculture system: $20.5 \%$ in spring barley and $21.7 \%$ in white goosefoot, $20.5 \%$ in spring barley and $20.4 \%$ in charlock. In the organic agriculture system, the highest concentration of crude protein in the biomass was established in prickly grass (18.9\%) and spring barley $(12.8 \%)$. The increase of crude protein concentration in white goosefoot, charlock and prickly grass induced the crude protein concentration increase in spring barley. The following relationship between the crude protein concentration was described by a linear correlation-regression analysis: in spring barley and white goosefoot $r=0.898(p<0.001)$, in spring barley and charlock $r=0.909(p<0.05)$, in spring barley and prickly grass $r=0.657(p>0.05)$. However, increase of the accumulated mass of crude protein in white goosefoot decreased the accumulated crude protein mass in spring barley: in the organic agriculture system $y=0.710-8.174 x, r=-0.74$ $(p<0.01)$ and in the conventional agriculture system $y=0.856-0.834 x$, $r=-0.07(p>0.05)$. The estimated negative dependence of the white goosefoot crude protein mass on the spring barley crude protein mass was in conformity with the Law of Crop Productivity.

Key words: competition, organic and conventional agriculture, Chenopodium album L., Echinochloa crus-galli (L.) Beauv., Hordeum vulgare L., Sinapis arvensis L., weeds 


\section{INTRODUCTION}

Fodders play a very important role in agriculture. Fodders are a source of nutrition for animals. Proteins as well as carbohydrates and lipids are called fundamental nutrition matters (Jeroch et al., 2010). They are macromolecular organic compounds consisting of peptide connections integrating amino acids (Jokubauskiene, 1998). In the experimental field study carried analysing winter wheat and spring barley crop weediness and nutrition matters assimilation by plants, it was established that weeds accumulate the most part of nutrition matters in the conventional agriculture system (Auškalnienè et al., 2002). Crop plant maturity is also a very important factor for nutrition accumulation. Spring barley silage chemical composition depended on the cereal stage of maturity (Pilipavičius, 2007). The research data regarding the chemical composition demonstrated that the chemical composition of weeds is similar to that of spring barley grains. However, weeds accumulate the greatest amount of crude protein, $14.6 \%$, growing in cropfree plots. Crude protein concentration in spring barley grains varied from $11.5 \%$ to $12.2 \%$ in crops of different thickness, 2.7-4.5-6.2 million seeds per ha ${ }^{-1}$ (Pilipavičius et al., 2011). Hence, weeds, except noxious ones, can enrich fodders by crude protein and mineral matters (Pilipavičius et al., 2003). Analysing the possibility of agronomical techniques for reducing crop damage by sika deer, it was established that only protein content differed among weeds, crops, and forest understory vegetation, with weeds exhibiting the highest protein content. The authors of this study concluded that sika deer are attracted to apple orchards because of the high protein content of the weeds growing there which should be controlled seeking to decrease crop damage by sika deer (Honda et al., 2010). Weed Amaranthus spinosus leaf meal as a dietary protein source is already suggested for feeding of fingerlings Clarias gariepinus (Adewolu, Adamson, 2011). To enrich fodders by crude protein and other components there are used various fodder additives and supplements as cyanobacteria Spirulina platensis (Šimkus et al., 2007; Kulpys et al., 2009). Dry biomass of Spirulina platensis has more proteins than barley, wheat and Chlorella vulgaris, their organic materials consist of $60-70 \%$ of proteins (Kupras et al., 2003).

Competition between domesticated, i. e. agricultural plants and weeds, has been commonly evaluated through biomass accumulation rather than crude protein concentration in it. These results show effectiveness of different weed species competition to spring barley under organic and conventional systems of agriculture.

The aim of the experiment was to establish the dependence of the concentration of spring barley biomass crude protein on the crude protein concentration in the white goosefoot, charlock and prickly grass biomass from the same agrophytocenosis.

\section{MATERIALS AND METHODS}

The Lithuanian territory occupies an intermediate geographical position between the west European oceanic climate and the Eurasian continental climate. Cold air masses transferred from the Arctic induce decrease of air temperatures which is the reason of spring and early autumn frosts and of hard frost in the wintertime. Warm air masses from tropics are seldom which form thaws during winter and clear hot days during summer. Climate of the Lithuanian territory forms in different radiation and circulation conditions. Differences in these conditions hardly cross the boundaries of microclimatic differences; therefore, Lithuania belongs to the western region of the Atlantic Ocean continental climatic area (Basalykas et al., 1958; Basalykas, 1968) with the average annual precipitation of $675 \mathrm{~mm}(572-978 \mathrm{~mm})$ and temperature of 6-7 ${ }^{\circ} \mathrm{C}$ (Vaitekūnas et al., 2007).

Spring barley Hordeum vulgare L., white goosefoot Chenopodium album L., charlock Sinapis arvensis L. and prickly grass Echinochloa crus-galli (L.) Beauv. were taken from the conventional and organic agriculture system agrophytocenosis of spring barley variety Aura. The field experiment from which plant samples were taken for the laboratorial bioassay was conducted in twofactor four replications. Factor A: organic and conventional agriculture. Factor B (spring barley stages of maturity by Zadoks et al., 1974): steam elongation, heading, early milk, medium milk, late milk-early dough, dough, hard.

Spring barley growing agrotechnics. Spring barley fore-crop grown in 2003 was black fallow (2002) 
and spring barley grown in 2004 on the same plot fore-crop was spring barley. Complex phosphorus $\mathrm{P}_{2} \mathrm{O}_{5}$, potassium $\mathrm{K}_{2} \mathrm{O}$ and nitrogen $\mathrm{N}$ fertilizers (160 kg ha ${ }^{-1}$ of active compounds) 'Azofoska' $(\mathrm{N}: \mathrm{P}: \mathrm{K}$ ratio $1: 1: 1$ by $16 \%)$ were applied on conventional spring barley in spring after sowing before sprouting. Spring barley of organic agriculture was not fertilised. Two-row barley Aura was sown during the first ten days of May sowing $200 \mathrm{~kg} \mathrm{ha}^{-1}$ (4.5 million seeds per ha-1) of seeds. The row distance was $12.5 \mathrm{~cm}$. Spring barley growing continuously after spring barley was disked in autumn barley stubble by $10-12 \mathrm{~cm}$ depth and after 4 weeks it was ploughed with mouldboard plough by $23-25 \mathrm{~cm}$ depth. Spring barley growing after black fallow in autumn was directly ploughed at $23-25 \mathrm{~cm}$ depth by mouldboard plough. In spring, after all preceding crops, soil was harrowed in 3-5 cm depth in early spring and loosened with harrowing at 3-5 $\mathrm{cm}$ depth before sowing. Herbicides and other pesticides in crops of spring barley were not applied.

Crop weediness was established by the quantity-weight method (Dospekhov et al., 1987).

Experimental field soil was clay loam of an average weight over moraine clay on sandy loam, deeper carbonaceous, gleyic luvisols (CalcariEpihypogleyic Luvisols - LVg-p-w-cc).

A more detailed description of the field experiment media and applied agrotechnics is given in our early publication (Pilipavičius, 2005). Sample plant crude protein concentration was determined by the Kjeldahl method (Naumann, Bassler, 1993a) at the Laboratory of Agronomic and Zootechnical Research of the Lithuanian University of Agriculture (Aleksandras Stulginskis University) at $54^{\circ} 89^{\prime} \mathrm{N}$ and $23^{\circ} 83^{\prime} \mathrm{E}$ during 2004-2005. The data quality of laboratorial analyses was determined by differences between parallels (3 replications) depending on the matter concentration found in the analysed sample. The results of analyses were achieved with the $95 \%$ level of probability in the permissible limits of error (Naumann, Bassler, 1993b). Relationship between the concentration of crude protein in spring barley, white goosefoot, charlock and prickly grass was established by a correlation-regression analysis. Dependence reliability was evaluated by the $p$ test. The data were evaluated using SigmaPlot 8.0 programmes (SPSS Science, 2000).

\section{RESULTS AND DISCUSSION}

In spring barley Hordeum vulgare L. crop agrophytocenosis grown under the conventional and the organic agriculture system annual weeds prevailed. Among annual weeds there were mostly spread white goosefoot Chenopodium album L., charlock Sinapis arvensis and prickly grass Echinochloa crusgalli (L.) Beauv. They comprise $87-97 \%$ (in one case $32 \%$ ) in the conventional and $66-94 \%$ in the organic agriculture system of the total weed air-dry biomass in the crop (Pilipavičius, 2005).

Evaluating the dependence of the concentration of spring barley biomass crude protein on the crude protein concentration in weeds, there was established a very interesting tendency - with increase of crude protein concentration in weeds (white goosefoot, charlock and prickly grass), it increased in spring barley as well (Figs. 1, 3-4). Spring barley and white goosefoot in the crop of organic agriculture are characterized by lower concentration of crude protein than in conventional agriculture (Fig. 1).

By analogy with spring barley and white goosefoot, in the crop of organic agriculture other annual dicotyledonous weed - charlock accumulated lower concentration of crude protein than in conventional agriculture (Fig. 3). It was influenced by the adequate plant (both weeds and spring barley) reaction to accumulate more intensive nutritional elements from soil because of light soluble nutrition increase in soil by mineral fertilization in plots of conventional

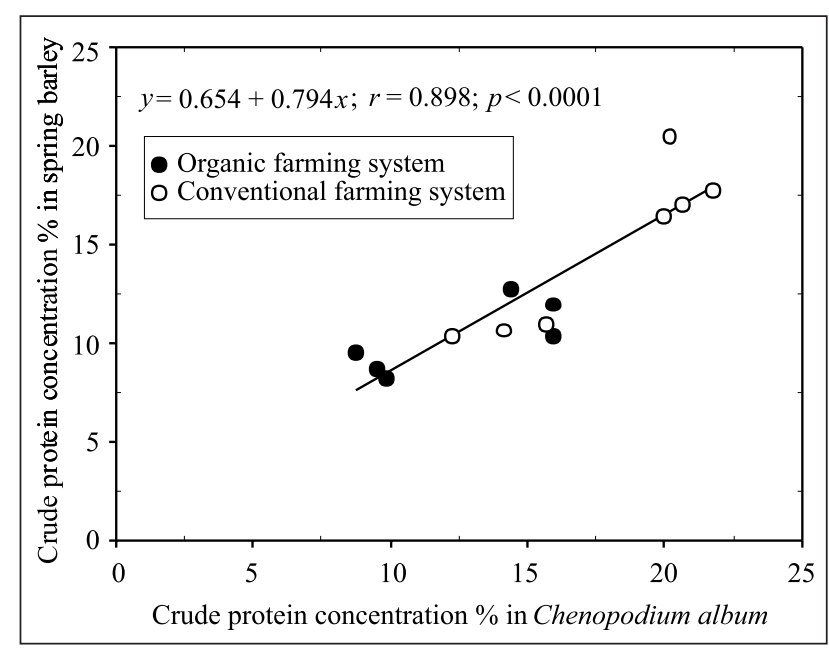

Fig. 1. Relationship between the concentration of crude protein in spring barley Hordeum vulgare and white goosefoot Chenopodium album 
agriculture. However, evaluating crude protein mass accumulated in white goosefoot and spring barley (Fig. 2) there was established the opposite effect on the crude protein concentration relationship, i. e. with increase of the accumulated crude protein mass in weeds, the crude protein mass in spring barley regularly decreased. A reliable decrease of crude protein mass accumulated in the spring barley biomass depending on the crude protein mass increase in white goosefoot of the organic agriculture system $r=-0.74(p<0.01)$ and the decrease tendency $r=-0.07(p>0.05)$ in the conventional agriculture system were established (Fig. 2).

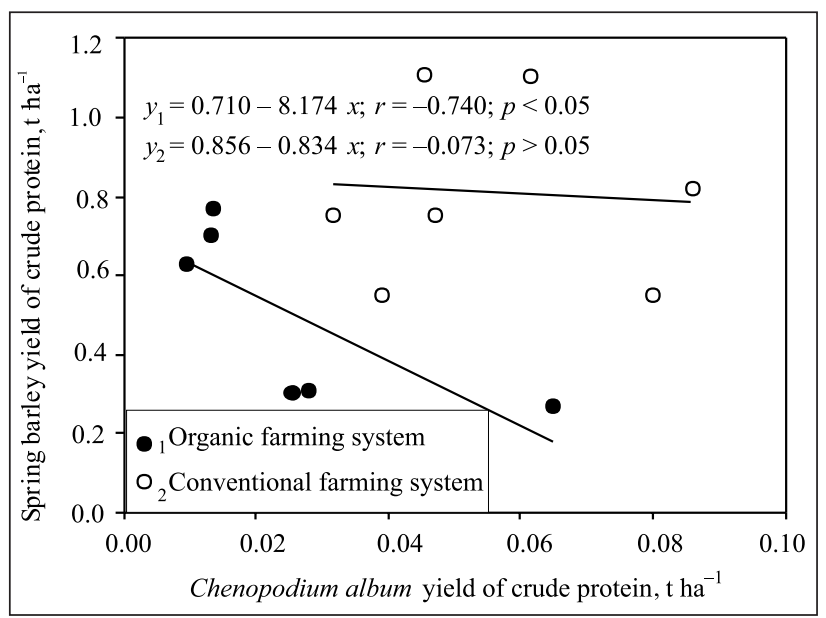

Fig. 2. Relationship between the yield of crude protein in spring barley Hordeum vulgare and white goosefoot Chenopodium album under the organic and conventional farming system

Growing intensively the spring barley crop, weeds accumulated more crude protein, therefore nitrogen was freely available in the intensively fertilised spring barley crop in conventional agriculture. Like weeds, spring barley also accumulated more crude protein in conventional than in organic agriculture. The stated interaction was similar to the Law of Crop Productivity which analyses the total crop plant biomass. Productivity of a crop - community of cultured plants and weeds - expressed by the total mass of cultured plants and weeds per area unit under the same plant growing conditions is relatively constant. Decreasing crop weediness (weed mass) the yield of cultural plants naturally increases, and on the contrary, increasing crop weediness the yield decreases in the inverse proportion (Lazauskas, 1990; 1993; 2013).

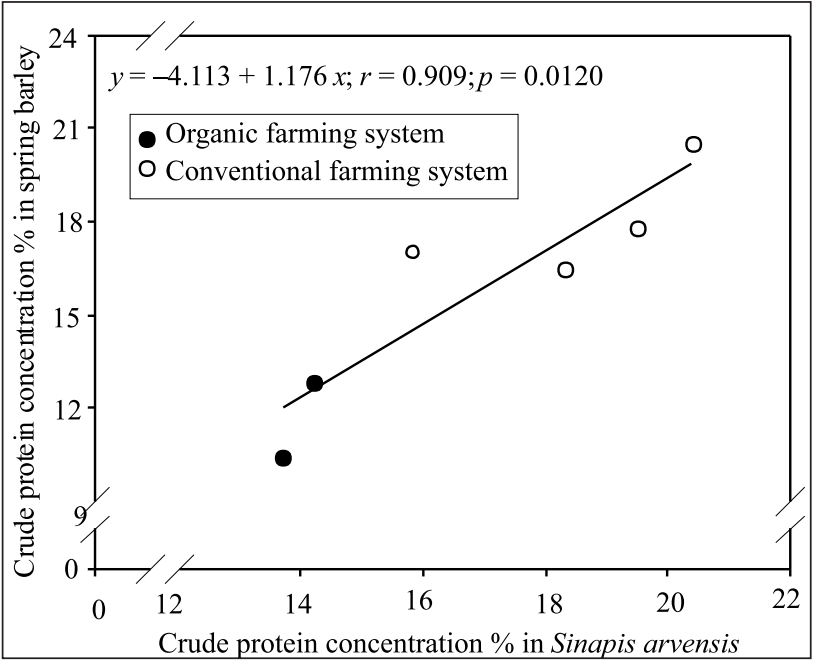

Fig. 3. Relationship between the concentration of crude protein in spring barley Hordeum vulgare and charlock Sinapis arvensis

Contrary to white goosefoot and charlock, prickly grass reached the highest crude protein concentration 19\% (variation limit 9-19\%) in the crop of organic agriculture. In the crop of conventional agriculture prickly grass accumulated about $15 \%$ crude protein concentration. Presumably, belonging to the same as spring barley monocotyledonous botanical plant group, prickly grass was more competitive with spring barley than white goosefoot and charlock. Spring barley in competition with prickly grass reached $8-12 \%$ of crude protein concentration in the biomass in the organic and $11 \%$ in the conventional agriculture system (Fig. 4), whereas spring barley competing

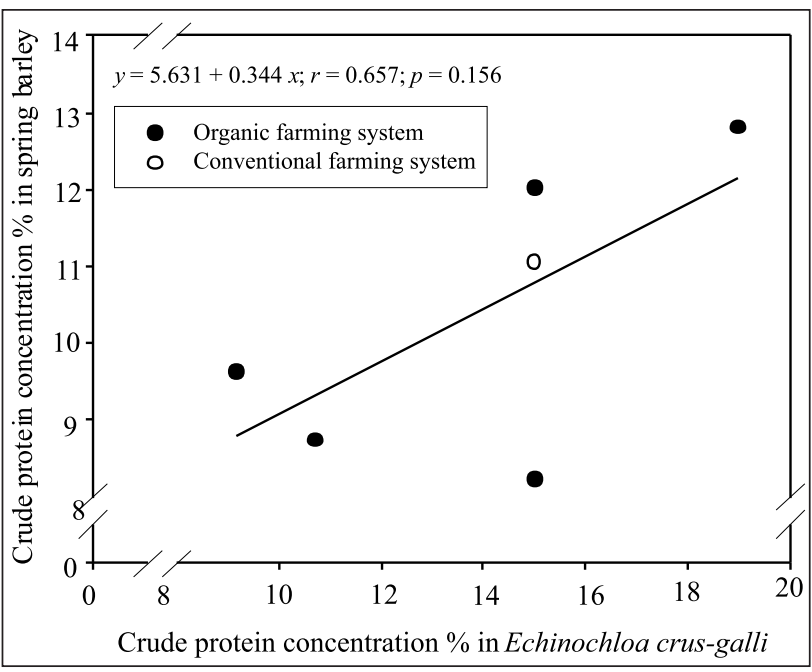

Fig. 4. Relationship between the concentration of crude protein in spring barley Hordeum vulgare and prickly grass Echinochloa crus-galli 
with white goosefoot (Fig. 1) and charlock (Fig. 3) accumulated to $20.5 \%$ and $13 \%$ of crude protein concentration in the biomass in the conventional and the organic agriculture system, respectively.

\section{CONCLUSIONS}

1. Prickly grass was more competitive weed than white goosefoot and charlock for spring barley while the spring barley biomass crude protein concentration was lowest in competition with prickly grass.

2. The highest concentration of crude protein was established in the conventional agriculture system in the biomass of spring barley Hordeum vulgare (20.5\%) and white goosefoot Chenopodium album (21.7\%), spring barley (20.5\%) and charlock Sinapis arvensis (20.4\%). In the organic agriculture system the highest concentration of crude protein was established in the biomass of prickly grass Echinochloa crus-galli (18.9\%) and spring barley (12.8\%).

3. Concentration of crude protein in white goosefoot, charlock and prickly grass increased as in spring barley. A positive relationship was established between the crude protein concentration in spring barley and white goosefoot $r=0.898$ $(p<0.001)$, spring barley and charlock $r=0.909$ $(p<0.05)$, spring barley and prickly grass $r=0.657$ $(p>0.05)$.

4. With increase of the crude protein mass in white goosefoot, the crude protein mass accumulated in the spring barley biomass regularly decreased: in the organic agriculture system $y=0.710-8.174 x, r=-0.74(p<0.01)$ and in the conventional agricultural system $y=0.856-0.834$ $x, r=-0.07(p>0.05)$.

\section{ACKNOWLEDGEMENTS}

We would like to thank Mrs. Vilma Pilipavičienè for her help in English paper corrections.

Received 17 June 2014 Accepted 10 December 2014

\section{REFERENCES}

1. Adewolu M. A., Adamson A. A. 2011. Amaranthus spinosus leaf meal as potential dietary protein source in the practical diets for Clarias gariepinus (Burchell, 1822) fingerlings. International Journal of Zoological Research. Vol. 7. No. 2. P. 128-137.

2. Auškalnienė O., Auškalnis A., Bučienè A., Antanaitis Š. 2002. Weediness and grain yield of spring barley and winter wheat in different cropping systems. Zemdirbyste-Agriculture. Vol. 79. No. 3. P. 123-130 (in Lithuanian, Summary in English).

3. Basalykas A., Bieliukas K., Chomskis V. 1958. Lietuvos TSR fizine geografija / Physical Geography of Lithuania. Vol. 1. Vilnius. 504 p. (in Lithuanian).

4. Basalykas A. 1965. Lietuvos TSR fizine geografija / Physical Geography of Lithuania. Vol. 2. Vilnius. 495 p. (in Lithuanian).

5. Honda T., Miyagawa Y., Suzuki Y., Yamasaki S. 2010. Possibility of agronomical techniques for reducing crop damage by sika deer. Mammal Study. Vol. 35. No. 2. P. 119-124.

6. Jeroch H., Sederevičius A., Pilipavičius V., Mikulionienè S., Steinhofel O., Matusevičius P., Stankevičius R. 2010. Pašarai - tradiciniai ir ekologiški. Futtermittel - konventionell und ökologisch / Feedstuffs - Conventional and Organic. Kaunas: Vitea Litera. 423 p. (in Lithuanian, Summary in English and German).

7. Jokubauskienè N. 1998. Baltymai / Proteins. Žemès ūkio enciklopedija. Vilnius: Mokslo ir enciklopedijų leidybos institutas. Vol. 1. P. 173174 (in Lithuanian).

8. Kulpys J., Paulauskas E., Pilipavičius V., Stankevičius R. 2009. Influence of cyanobacteria Arthrospira (Spirulina) platensis biomass additives towards the body condition of lactation cows and biochemical milk indexes. Agronomy Research. Vol. 7. No. 2. P. 823-835.

9. Kupras L. P., Cekman I. S., Gorcakova N. A. 2003. Spirulina platensis and the Health. Kiev: The Ukrainian Academy of Medicine Sciences. $86 \mathrm{p}$.

10. Lazauskas P. 1990. Agrotechnika prieš piktžoles: monografija / Agrotechnics Against Weeds: Monography. Vilnius: Mokslas. 214 p. (in Lithuanian, Summary in English).

11. Lazauskas P. 1993. The Law of Crops Performance as a Basis of Weed Control. Quantitative Approaches in Weed and Herbicide Research and their Practical Application: 8th EWRS Symposium Proceedings. Braunschweig, Germany. P. 71-77.

12. Lazauskas P. 2013. Pasèlių produktyvumo dèsnis teoriniam-abstrahuotam agrofitocenozès vertinimui vietoj tradicinio empirinio / The abstract theoretical cognition of productivity of agricultural plant communities instead of the empirical cognition. Žemés ūkio mokslai - Agricultural Sciences. Vol. 20. No. 4. P. 308-321 (in Lithuanian, Summary in English).

13. Naumann C., Bassler R. 1993a. Bestimmung von Rohprotein (Amtliche Methode). Die chemische 
Untersuchung von Futtermitteln. Metodenbuch III, 3 Erg. Darmstadt: VDLUFA-Verlag. No. 4.1.1. S. $1-5$.

14. Naumann C., Bassler R. 1993b. Analysenspielräume. Die chemische Untersuchung von Futtermitteln. Metodenbuch III, 3 Erg. Anhang. Darmstadt: VDLUFA-Verlag. S. 1-10.

15. Pilipavičius V., Mikulionienè S., Stankevičius R. 2003. Chemical composition and feed value for ruminants of weedy maize silage. Veterinarija ir zootechnika. Vol. 21. No. 43. P. 90-92.

16. Pilipavičius V. 2005. Competition of weeds and spring barley in organic and conventional agriculture. Vagos. Vol. 68. No. 21. P. 30-43 (in Lithuanian, Summary in English).

17. Pilipavičius V. 2007. Whole plant silage nutritive value from spring barley of different maturity. Veterinarija ir zootechnika. Vol. 37. No. 59. P. 6166.

18. Pilipavičius V., Romaneckienè R., Romaneckas K. 2011. Crop stand density enhances competitive ability of spring barley (Hordeum vulgare L.). Acta Agriculturae Scandinavica. Section B: Soil and Plant Science. Vol. 61. No. 7. P. 648-660.

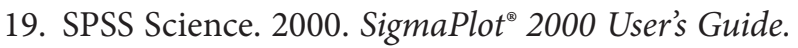
Exact Graphs for Exact Science. USA. 435 p.

20. Šimkus A., Oberauskas V., Laugalis J., Želvytė R., Monkevičienė I., Sederevičius A., Šimkienè A., Pauliukas K. 2007. The effect of weed Spirulina platensis on the milk production in cows. Veterinarija ir zootechnika. Vol. 38. No. 60. P. 7477 (in Lithuanian, Summary in English).

21. Vaitekūnas S. 2007. Klimatas / Climate. Visuotiné lietuviu enciklopedija / Universal Lithuanian Encyclopedia. Vilnius: Mokslo ir enciklopedijų leidybos institutas. Vol. 12. P. 47-57 (in Lithuanian).

22. Zadoks J. C., Chang T. T., Konzak C. F. 1974. A decimal code for the growth stages of cereals. Weed Research. Vol. 14. No. 6. P. 415-421.

23. Dospekhov B. A., Vasil'ev I. P., Gulikov A. M. 1987. Praktikum po zemledeliyu. Moskva. 383 s.

\section{Vytautas Pilipavičius}

VASARINIŲ MIEŽIŲ (HORDEUM VULGARE L.) ŽALIŲ PROTEINŲ KONCENTRACIJOS PRIKLAUSOMUMAS NUO ŽALIŲ PROTEINŲ AKUMULIACIJOS BALTOJOJE BALANDOJE ( $\mathrm{CHE}^{-}$ NOPODIUM ALBUM L.), GARSTUKE (SINAPIS ARVENSIS L.) IR PAPRASTOJOJE RIETMENĖJE (ECHINOCHLOA CRUS-GALLI (L.) BEAUV.)

Santrauka

Laboratorinis tyrimas atliktas Lietuvos žemès ūkio universiteto (dabar - Aleksandro Stulginskio universitetas) Agronominių ir zootechninių tyrimų laboratorijoje $\left(54^{\circ} 89^{\prime} \mathrm{N}\right.$ ir 2383'E) 2004-2005 m. Lauko eksperimentas, iš kurio paimti augalų méginiai laboratoriniam tyrimui, atliktas
2003-2004 m. vasarinių miežių 'Aura' pasėlyje Lietuvos žemès ūkio universiteto Bandymų stotyje $\left(54^{\circ} 52^{\prime} \mathrm{N}\right.$ ir $\left.23^{\circ} 49^{\prime} \mathrm{E}\right)$.

Lietuvos teritorija užima tarpinę geografinę vietą tarp Vakarų Europos okeaninio ir Eurazijos kontinentinio klimato. Lietuva priklauso Atlanto vandenyno kontinentinio klimato vakarų regiono teritorijai. Vidutinis metinis kritulių kiekis - $675 \mathrm{~mm}$ (572-978 mm), vidutiné oro temperatūra $-6-7^{\circ} \mathrm{C}$.

Žalių proteinų koncentracijos pokyčiai pasèlio piktžolèse turëjo ịtakos žalių proteinų akumuliacijai vasariniuose miežiuose. Eksperimento tikslas - jvertinti vasarinių miežių žalių proteinų biomasès koncentracijos priklausomumą nuo žalių proteinų koncentracijos baltosios balandos, garstuko ir paprastosios rietmenès biomasèje, akumuliuotoje toje pačioje agrofitocenozejje. Pasèlio augalų, paimtų iš ekologinès ir tradicinès žemdirbystès sistemų, žalių proteinų koncentracija biomaseje nustatyta Kjeldalio metodu.

Didžiausia žalių proteinų koncentracija aptikta tradicinès žemdirbystès sistemos vasariniuose miežiuose (20,5\%), baltojoje balandoje $(21,7 \%)$ ir garstukuose $(20,4 \%)$. Ekologinès žemdirbystès sistemoje didžiausia žalių proteinų koncentracija nustatyta paprastojoje rietmenèje $(18,9 \%)$ ir vasariniuose miežiuose (12,8 \%). Žalių proteinų koncentracijos didejjimas baltojoje balandoje, garstuke ir paprastojoje rietmenëje didino ir žalių proteinų koncentraciją vasarinių miežių biomaseje. Nustatyti tiesiniai teigiami priklausomumai tarp žalių proteinų koncentracijos vasariniuose miežiuose ir baltojoje balandoje $r=0,898(p<0,001)$, vasariniuose miežiuose ir garstuke $r=0,909(p<0,05)$, vasariniuose miežiuose ir paprastojoje rietmenèje $r=0,657$ ( $p>0,05)$. Didejjant sukauptai žalių proteinų masei baltojoje balandoje (analogiškai pasèlių produktyvumo dèsniui), žalių proteinų masė vasariniuose miežiuose sistemingai mažèjo ekologinès žemdirbystès sistemoje (atitinkamai regresijos lygčiai $y=0,710-8,174 x$, $r=-0,74(p<0,01))$ ir tradicinès žemdirbystès sistemoje (atitinkamai regresijos lygčiai: $y=0,856-0,834 x, r=-0,07$ $(p>0,05))$.

Raktažodžiai: konkurencingumas, ekologinè ir tradiciné žemdirbystè, Chenopodium album L., Echinochloa crusgalli (L.) Beauv., Hordeum vulgare L., Sinapis arvensis L., piktžolès 